\title{
Characterization of progesterone loaded biodegradable blend polymeric nanoparticles
}

\author{
Caracterização de nanopartículas blenda poliméricas \\ biodegradáveis contendo progesterona
}

\author{
Fernanda Vitória Leimann ${ }^{I}$ Maiara Heloisa Biz ${ }^{\text {II }}$ Karine Cristine Kaufmann ${ }^{\text {III }}$ \\ Wallace José Maia' ${ }^{\text {III }}$ Odinei Hess Honçalves ${ }^{\text {II }}$ Lucio Cardozo Filho $^{\text {IV }}$ \\ Claudia SayerII Pedro Henrique Hermes de AraújoII
}

\begin{abstract}
The encapsulation of progesterone in poly (hydroxybutirate-co-hydroxyvalerate) (PHBV), poly (E-caprolactone) (PCL), poly (L-lactic acid) (PLLA) nanoparticles and PHBV/PCL and PHBV/PLLA blend nanoparticles was investigated in this research. Nanoparticles were produced by miniemulsion/solvent evaporation technique with lecithin as surfactant and were characterized regarding to z-average diameter (Dz) and polydispersity (PDI), progesterone recovery yield and encapsulation efficiency. Possible interactions between progesterone and the polymer matrices were investigated by Fourier Transform Infrared Spectroscopy (FTIR). High recoveries (up to $102.43 \pm 1.80 \%$ for the PHBV/PLLA blend) and encapsulation efficiencies (up to $99.53 \pm 0.04 \%$ for $P C L$ ) were achieved and the nanoparticles

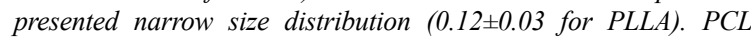
nanoparticles $(217.5 \pm 2.12 \mathrm{~nm})$ presented significant difference with the $D z$ from all the other formulations $(P<0.05)$. The most evident interaction between progesterone and the nanoparticles polymeric matrix was found to PHBV/PCL due to the increase in the intensity of the band located in $1631 \mathrm{~cm}^{-1}$.
\end{abstract}

Key words: progesterone, drug-polymer interactions, $P H B V$, PLLA, PCL.

\section{RESUMO}

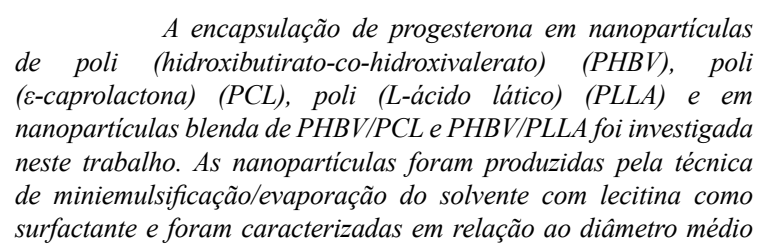

em intensidade $(\mathrm{Dz})$ e o índice de polidispersão (PDI), rendimento de recuperação e eficiência de encapsulação de progesterona. Possiveis interações entre progesterona e as matrizes poliméricas foram investigadas por Espectroscopia de Infravermelho por Transformada de Fourier (FTIR). Valores elevados de rendimento de recuperação (de até 102,43 1,80\% para a blenda PHBV/PLLA)

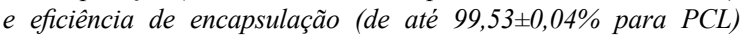
foram obtidos e as nanopartículas apresentaram distribuição de tamanho estreita $(0,12 \pm 0,03$ para PLLA). As nanopartículas de $P C L(217,5 \pm 2,12 \mathrm{~nm})$ apresentaram diferença significativa com todas as outras formulações $(P<0,05)$ quanto ao Dz. A interação mais evidente entre progesterona e a matriz polimérica das nanopartículas foi para a blenda PHBV / PCL, devido ao aumento na intensidade da banda localizada em $1631 \mathrm{~cm}^{-1}$.

Palavras-chave: progesterona, interações polímero-droga, $P H B V$, PLLA, PCL.

\section{INTRODUCTION}

Estrous synchronization and artificial insemination remain the most important and widely applicable reproductive biotechnologies available for cattle. Use of artificial insemination in cattle has allowed the introduction of highly successful genetic improvement programs for increasing milk yield and has reduced the incidence of several diseases (PATTERSON et al., 2013). Estrous control in cattle can be achieved by the administration of progesterone (pregn-4-ene-3,20-dione) during 5-9 days inhibiting

'Programa de Pós-graduação em Tecnologia de Alimentos (PPGTA), Universidade Tecnológica Federal do Paraná (UTFPR), Campus Campo Mourão, Via Rosalina Maria dos Santos, 1233, CP 271, 87301-899, Campo Mourão, PR, Brasil. E-mail: fernandaleimann@utfpr.edu.br. Corresponding author.

"Departamento de Engenharia Química e Engenharia de Alimentos, Universidade Federal de Santa Catarina (UFSC), Florianópolis, SC, Brasil.

IIIDepartamento Acadêmico de Alimentos (DALIM), UTFPR, Campo Mourão, PR, Brasil.

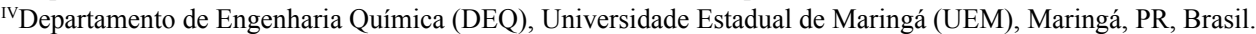


the luteinizing hormone (LH) secretion (NEVES et al., 2010). Currently available intravaginal inserts for estrous control of cattle comprise " $\mathrm{Y}$ " or " $\mathrm{T}$ " shaped silicone matrices containing homogenously dispersed progesterone (RATHBONE et al., 1998; RATHBONE et al., 2002). Their objective is not only provide sustained release but to facilitate handling and application in the cattle.

Although silicone presents biocompatibility it is not considered biodegradable and the inserts must be removed after the dosage period. Studies have proven that silicone can be substituted by polymers that present both characteristics, biocompatibility and biodegradability, eg. poly (hydroxybutirateco-hydroxyvalerate) (PHBV) and poly (epsloncaprolactone) (PCL). (PIMENTEL, 2010). LEIMANN et al. (2013) demonstrated that PHBV nanoparticles showed a capacity for rapid hydrolytical degradation with a pronounced decrease of the molecular weight ( $\mathrm{pH}$ values, 2.5 and 7.0, at 4 and $37^{\circ} \mathrm{C}$ ). CHAWLA E AMIJI (2002) demonstrated that PCL nanoparticles were completely degraded after $36 \mathrm{~h}$ in the presence of lipase. Therefore the use of these biodegradable and commercial evaluable polymers can be an interesting alternative to replace the silicone devices.

Biopolymer micro and nanoparticles have been proposed as an alternative to encapsulate progesterone (JAMEELA et al., 1998; LEMOSSENNA et al., 1998; MATSUMOTO et al., 1999; LATHA et al., 2000; SILVA et al., 2006; SALEM, 2010). It is worth noting that besides the controlled delivery, encapsulation also provides protection from premature degradation during handling and storage before use, enhancement of absorption and bioavailability, improved retention time inside the organism and improvement of intracellular penetration (KUMARI et al., 2010).

Nanoparticles production technique must be flexible to obtain nanoparticle with different properties, enabling to modify the polymer matrix composition and to use pure polymer and blend or hybrid nanoparticles. This could result in different drug concentration inside the particles and modulated progesterone release in different hydrolysis rate (BAJPAI et al., 2008; CAN et al., 2011). Polymer structure in the nanometer size range can be modified to better suit biocompatibility, bio-recognition and biological systems integration (WEST and HALAS, 2000), which is a feasible way to reach polymer blend nanoparticles. An advantage about the miniemulsion/ solvent evaporation technique is that it does not require any chemical modification of the polymer structure and it is applicable to virtually any material that is sufficiently hydrophobic to be considered immiscible with water and that forms a solid phase after solvent evaporation (KIETZKE et al., 2003). Furthermore, progesterone has no solubility in water making this the ideal system for its encapsulation.

In this research progesterone-loaded blend nanoparticles produced by miniemulsion/ solvent evaporation technique with PHBV, PCL and PLLA were characterized within their morphology, $\mathrm{Z}$-average size $(\mathrm{Dz})$ and polydispersion index (PDI), progesterone recovery yield (RY\%) and encapsulation efficiency $(\mathrm{EE} \%)$ as well as the chemical interactions between the polymeric matrices and the drug.

\section{MATERIAL AND METHODS}

\section{Material}

PHBV (8.2 HV mol\%; Mw 255,660g.mol ${ }^{-1}$ ) and PCL were kindly supplied by PHB Industrial S.A. Sodium borohydride $\left(\mathrm{NaBH}_{4}\right)$, chloroform, hexane, and methanol (Nuclear, P.A.) were used in the molecular weight reduction of PHBV. The dimer L-lactide (Purasorb L, Purac), tin II 2 ethylhexanoate (catalyst, Sigma Aldrich, 99.5\% purity), gaseous nitrogen (99.9\% purity), methanol, chloroform and tetrahydrofuran were used for PLLA synthesis. All reactants were used as received without further purification. Progesterone was supplied by INDEX Farmacêutica (99.98\%) and lecithin (Alfa Aesar) was used as surfactant.

\section{PHBV Purification and molecular weight reduction}

To purify PHBV and reduce its molecular weight the procedure described by LEIMANN et al. (2013) was adopted. Briefly, PHBV was solubilized in chloroform, precipitated in hexane and dried at $60^{\circ} \mathrm{C}$. After that PHBV (15g) was dissolved in chloroform $(400 \mathrm{ml})$ and $\mathrm{NaBH}_{4}(130 \mathrm{mg})$ was dissolved in methanol $(44 \mathrm{ml})$. Both solutions were mixed and stirred during $6 \mathrm{~h}$ at room temperature. Finally, PHBV was precipitated in cold methanol, filtered under vacuum and dried at $60^{\circ} \mathrm{C}$.

\section{PLLA Synthesis}

L-lactide ring opening polymerization was carried out as described by NIJENHUIS et al. (1992) and HYON et al. (1997) with some modifications. L-lactide and catalyst were allowed to react in ampoules in an oil bath at $140^{\circ} \mathrm{C}$ for 24 hours. After that the ampoules were immediately quenched in cold methanol $\left(10^{\circ} \mathrm{C}\right)$. The L-lactide/catalyst molar ratio used was $5,000 \mathrm{~mol}_{\text {L-lactide }} / \mathrm{mol}_{\text {catalyst }}$ as suggested by HYON et al. (1997). 
Nanoparticles preparation

Nanoparticles of pure PHBV, PCL and PLLLA and blend nanoparticles of PHBV/PCL and PHBV/PLLA were prepared as described by MUSYANOVYCH et al. (2008). The organic phase was prepared dissolving lecithin $(0.175 \mathrm{~g})$, polymer $(0.3 \mathrm{~g})$ and progesterone $(5 \mathrm{mg}$ or $0 \mathrm{mg}$ ) in chloroform $(10 \mathrm{~g})$. The organic phase was then added to the water $(24 \mathrm{~g})$ and stirred (1000rpm) for 60min. Miniemulsification was performed in an ice bath using sonication for $180 \mathrm{~s}$ at $100 \%$ amplitude in a pulsed regime (30s sonication, 10s pause) using a Fisher-Scientific - Ultrasonic Dismembrator $120 \mathrm{~W}$ sonifier and a $1 / 8$ " tip. The miniemulsion was then kept overnight at $40^{\circ} \mathrm{C}$ to complete chloroform evaporation.

Nanoparticles and polymers characterization

The z-average diameter (Dz) and polidispersion indexes (PDI) of nanoparticles were determined by Dynamic Light Scattering (Malvern Nanosizer - Nano Series). Progesterone recovery yield (RY \%) and encapsulation efficiency (EE $\%$ ) were determined by High Performance Liquid Chromatography (HPLC, Ultimate 3000, Dionex) in triplicate according to the methodology described by PEREIRA et al. (2000). The conditions employed to the analysis were the following: methanol:water $(75: 25, \mathrm{v} / \mathrm{v})$ as mobile phase at $1 \mathrm{~mL} \mathrm{~min}^{-1}$, column X-bridge (Waters) (C18 $5 \mu \mathrm{m} 4.6 \mathrm{~mm} \mathrm{x} \mathrm{150mm} \mathrm{-}$ $37^{\circ} \mathrm{C}$ ) and detection at $245 \mathrm{~nm}$. The RY \% represents the relation between the total mass of progesterone determined by HPLC $\left(\mathrm{m}_{\mathrm{TP}}\right)$ and the total mass added in the formulation $\left(\mathrm{m}_{0}\right)$ (Equation 1). The $\mathrm{EE} \%$ represents the progesterone actually entrapped inside the nanoparticles $\left(\mathrm{m}_{\mathrm{AP}}\right)$ (Equation 2$)$.

$$
\begin{aligned}
& \mathrm{RY} \%=\frac{\mathrm{m}_{\mathrm{TP}} \cdot 100}{\mathrm{~m}_{0}} \\
& E E \%=\frac{\left(\mathrm{m}_{\mathrm{TP}}-\mathrm{m}_{\mathrm{AP}}\right) \cdot 100}{\mathrm{~m}_{\mathrm{TP}}}
\end{aligned}
$$

Infrared spectra of nanoparticles components, progesterone loaded nanoparticles and blank nanoparticles were obtained by scans taken from 4000 to $500 \mathrm{~cm}^{-1}$ with 32 accumulations on a Shimadzu (IR AFFINITY-1) spectrometer.

\section{Statistical analysis}

Encapsulation recovery, efficiency and the nanoparticles size were evaluated using one-way ANOVA followed by Tukey post hoc test. Differences were considered statistically significant when the p-value was less than 0.05 and the calculations were carried out using Statistica 7.0 (StatSoft, Tulsa, USA).

\section{RESULTS AND DISCUSSION}

Recovery yield and encapsulation efficiency of progesterone in the synthesized nanoparticles are presented in table 1 . All recovery yields presented high values with no significant difference $(p>0.05)$ meaning that no loss of progesterone during the encapsulation procedure could be observed. SOUZA et al. (2011) produced lipid nanoparticles containing the dug topotecan and observed that low recovery values of the encapsulated drug were related to losses during the preparation process and also by chemical degradation. Accordingly to CHORNY et al. (2002) the drug recovery yield can be effectively controlled by readily adjusted preparation parameters. Table 1 results indicated that the progesterone-loaded nanoparticles were stable during the synthesis process as well as that miniemulsion/ solvent evaporation technique is a suitable technique to encapsulate progesterone. Encapsulation efficiencies were high for all formulations with slightly small values for PLLA and PCL. Progesterone was efficiently encapsulated in the blend nanoparticles. MATSUMOTO et al. (1999) obtained encapsulation efficiency results up to $74 \%$ for PLA-PEG-PLA nanoparticles synthesized by the same technique of the present research with some modifications. The higher

Table 1 - Progesterone recovery yield (RY), encapsulation efficiency (EE), z-average diameter (Dz) and polydispersity (PDI) of PHBV, PLLA, PCL, PHBV/PLLA and PHBV/PCL nanoparticles.

\begin{tabular}{lllll}
\hline Polymer & RY $(\%)$ & EE (\%) & Dz (nm) & PDI (-) \\
\hline PHBV/PCL & $95.4 \pm 4.6$ & $98.7^{\mathrm{a}} \pm 0.0$ & $161.1^{\mathrm{a}} \pm 1.4$ & $0.3 \pm 0.1$ \\
PHBV/PLLA & $102.4 \pm 1.8$ & $99.1^{\mathrm{a}, \mathrm{b}} \pm 0.4$ & $153.5^{\mathrm{a}} \pm 13.4$ & $0.2 \pm 0.1$ \\
PHBV & $100.2 \pm 1.5$ & $99.4^{\mathrm{a}, \mathrm{b}} \pm 0.2$ & $144.5^{\mathrm{a}} \pm 3.5$ & $0.2 \pm 0.0$ \\
PLLA & $101.2 \pm 2.3$ & $99.5^{\mathrm{b}} \pm 0.1$ & $155.0^{\mathrm{a}} \pm 15.6$ & $0.1 \pm 0.0$ \\
PCL & $100.4 \pm 1.6$ & $99.5^{\mathrm{b}} \pm 0.1$ & $217.5^{\mathrm{b}} \pm 2.1$ & $0.1 \pm 0.0$ \\
\hline
\end{tabular}

Significant differences between the results are denoted by different letters $(p<0.05)$. 
results obtained at the present research can be explained by the hydrophobic characteristics of PLLA, PCL and PHBV that present more affinity with progesterone than with the copolymer used by MATSUMOTO et al. (1999). The addition of hydrophilic segments (PEG) into the hydrophobic PLA homopolymer reduced the encapsulation efficiency.

The z-average size (Dz) and polydispersion index (PDI) of the nanoparticles containing progesterone are presented in table 1. All formulations yielded particles in the nanometric range. Also, low polydispersity indexes were found with no significant difference $(\mathrm{P}>0.05)$. BYUN et al. (2011) prepared $\alpha$-tocopherol-loaded PCL nanoparticles by emulsion solvent evaporation using a sonication apparatus. The average nanoparticles size obtained by the authors remained between 247 and 1070nm using poly (vinil alcohol) as surfactant. MUSYANOVYCH et al. (2008) produced PCL nanoparticles with lutensol as surfactant and obtained similar results as those presented in table 1.

Figure 1 presents the infrared spectra of all the components used in the nanoparticles preparation along with some characteristic absorption bands. In figure 2 the infrared spectra of the progesteroneloaded and blank nanoparticles are presented.

Lecithin presented a strong band at 2855 $\mathrm{cm}^{-1}$, a band located at $2930 \mathrm{~cm}^{-1}$ with a shoulder at $2956 \mathrm{~cm}^{-1}$ and a small band at $3010 \mathrm{~cm}^{-1}$ due to the $\mathrm{CH}$ stretching (CAVALLARO et al., 1995). These bands could be found in figure 1 (highlighted area). The $\mathrm{P}-\mathrm{O}-\mathrm{C}$ and $\mathrm{PO}^{4-}$ lecithin groups were also found at $1050 \mathrm{~cm}^{-1}$ (RUGGIRELLO and LIVERI, 2003). CERCHIARA et al. (2003) described that progesterone has characteristic bands located at 1661 $\mathrm{cm}^{-1}$ and $1698 \mathrm{~cm}^{-1}$ corresponding to the carbonyl groups (C3-cyclic and $\mathrm{C} 20$-linked to methyl radical). In figure 1 these bands are located at $1656 \mathrm{~cm}^{-1}$ and $1703 \mathrm{~cm}^{-1}$ respectively in progesterone spectra. The characteristic band of the double bond of progesterone is located between 850 and $900 \mathrm{~cm}^{-1}$ (LANCASTER et al., 2007). Progesterone band located at $870 \mathrm{~cm}^{-1}$ is also found in figure 1. For PCL, PLLA and PHBV the characteristic band of polyesters related to the $\mathrm{C}=\mathrm{O}$ stretching could be found at approximately $1700 \mathrm{~cm}^{-1}$ (POLETTO et al., 2007).

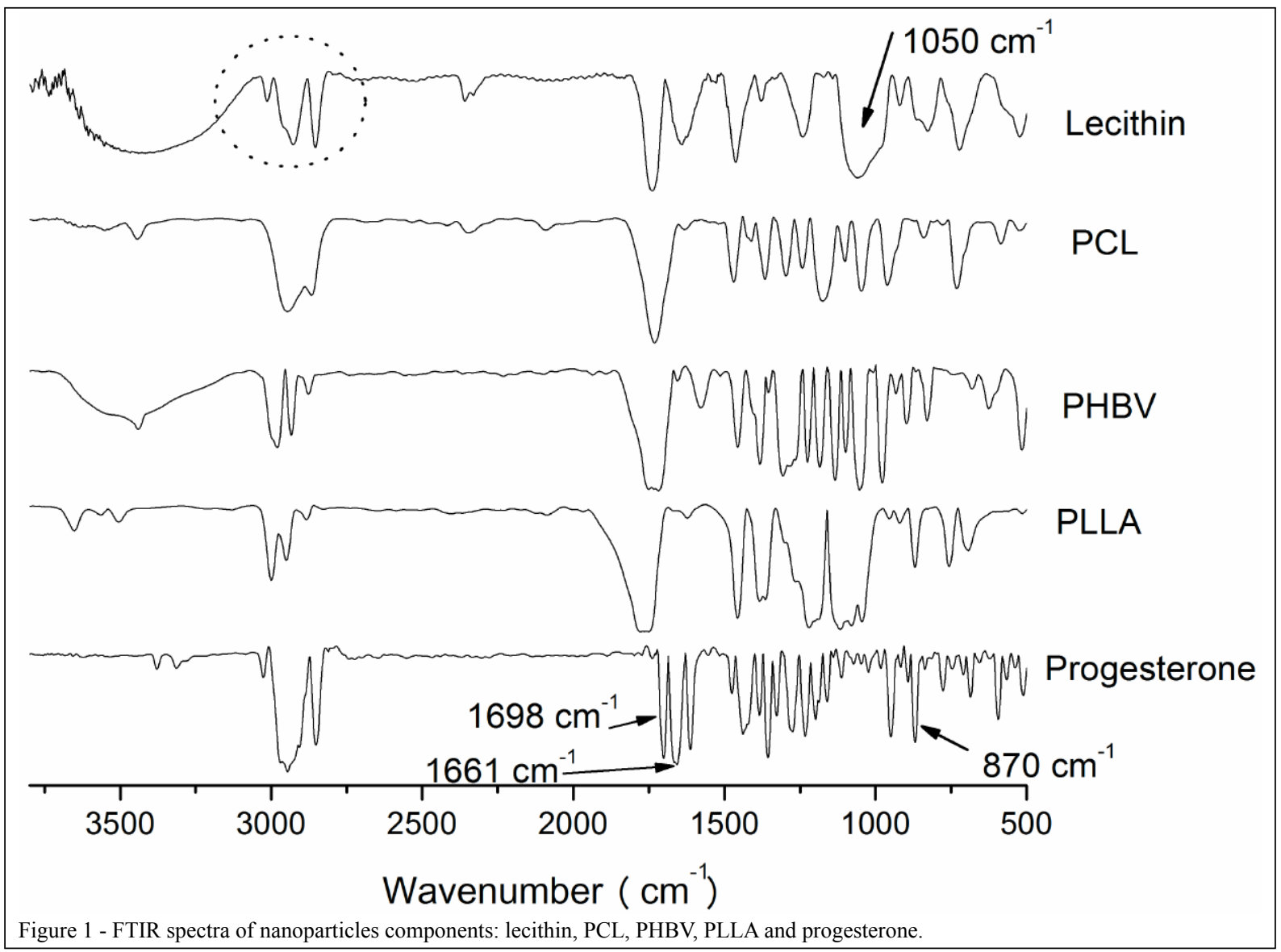

Ciência Rural, v.45, n.11, nov, 2015. 


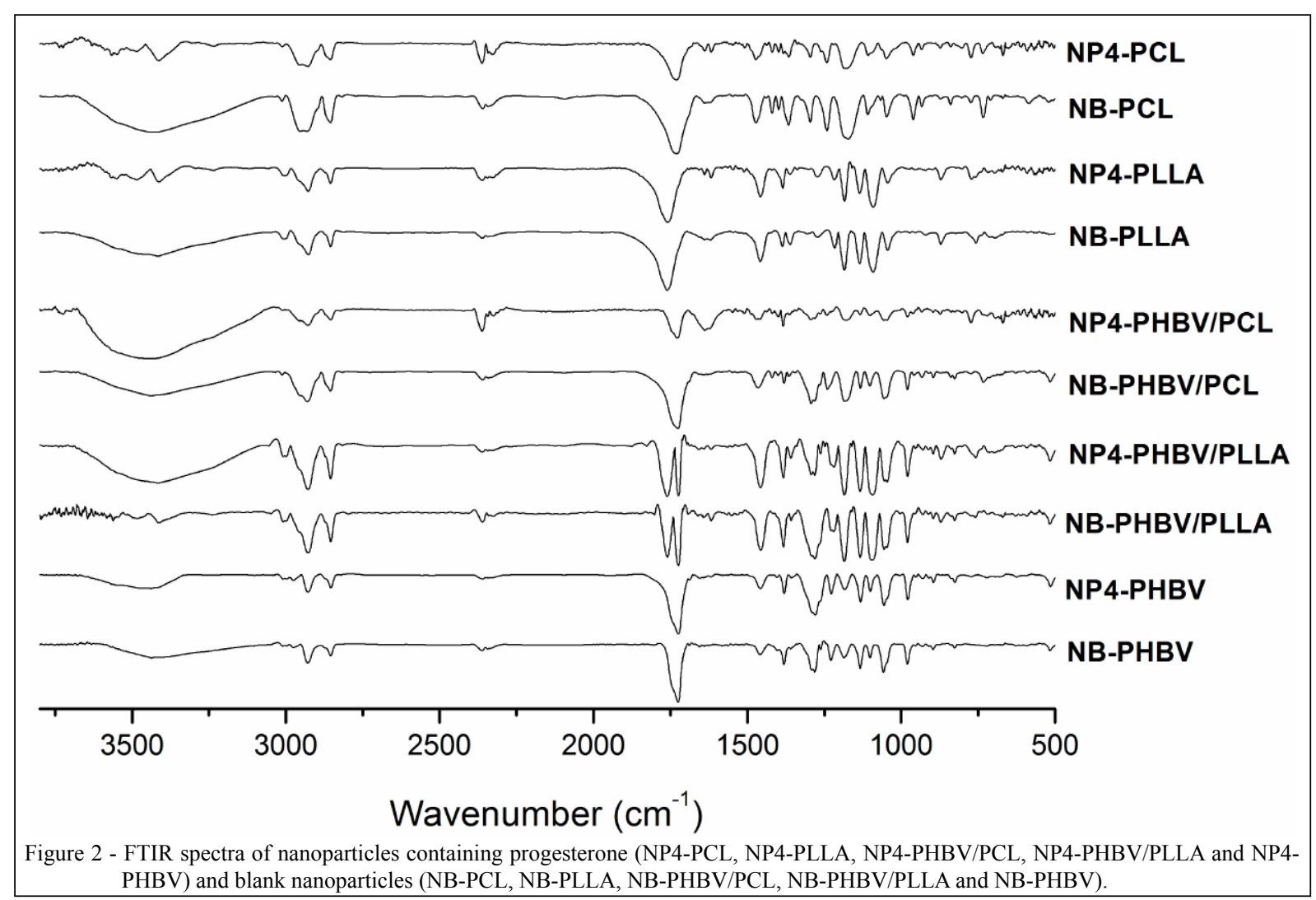

It was possible to observe in figure 2 that for PHBV nanoparticles, in both progesterone-loaded and blank nanoparticles, the lecithin bands related to $\mathrm{CH}$ stretching modes are similar to pure lecithin spectra (Figure 1). However all the other polymeric nanoparticles presented an increase in the intensity of the shoulder located at $2956 \mathrm{~cm}^{-1}$. This behavior is clearer for PCL and PHBV/PCL nanoparticles. EDWARDS et al. (1993) point out that such behavior indicates an increase in the crystallinity degree of the alkyl side chain of lecithin.

Progesterone bands regarding to $\mathrm{C}=\mathrm{O}$ stretching at $\mathrm{C} 3$ and $\mathrm{C} 20$ shifted to $1654 \mathrm{~cm}^{-1}$ and $1614 \mathrm{~cm}^{-1}$ in all nanoparticles spectra contacting progesterone. According to LIU et al. (2004) the presence of shifts or changes in the polymer-drug spectrum is an indication that they are chemically interacting. DEV et al. (2010) encapsulated lamivudine in PLA and chitosan nanoparticles and compared the FTIR spectra of black nanoparticles to nanoparticles containing the drug. They observed a widening of the lamivudine band located between 1000 and $1100 \mathrm{~cm}^{-1}$. The authors concluded that this behavior indicated the interaction between the drug and polymer as well as confirms their incorporation into polymeric nanoparticles. In general one can conclude that all formulations interactions took place between progesterone and the biopolymers due to the observed changes in the FTIR spectra. The most evident interaction observed in figure 2 is between progesterone and PHBV/PCL nanoparticles, due to the increase in the intensity and enlargement of the band located at $1631 \mathrm{~cm}^{-1}$. This is in agreement with the results found by PIMENTEL (2010) that evaluated the progesterone release from PHBV and PHBV/PCL microparticles and found that during $12 \mathrm{~h}$ of analysis PHBV released up to $95 \%$ of the drug while the blends of PHBV/PCL released up to $77 \%$ of the drug in the same period.

DAS et al. (2010) used FTIR to determine the potential interactions between the components of nanoparticles (alginate, chitosan and pluronic) containing curcumin. SAWANT et al. (2010) demonstrated by FTIR spectra that there was no interaction between the drug lidocaine encapsulated in hydrophobic Eudragit polymers, since the spectrum did not presented any changes with respect to the spectra of the components when analyzed isolated.

\section{CONCLUSION}

PHBV, PLLA, PCL as well as PHBV/ PCL and PHBV/PLLA blends demonstrated to be suitable encapsulation agents for progesterone. All 
the biopolymers and blends used presented narrow size distributions, high encapsulation efficiency and high drug loading, indicating that the technique and the tested biopolymers are indicated for the proposed application. The interactions between progesterone and the polymeric matrix were evidenced by FTIR spectra, showing a stronger interaction with the PHBV/PCL blend.

\section{ACKNOWLEDGEMENTS}

The authors thank Coordenação de Aperfeiçoamento de Pessoal de Nível Superior (CAPES) e Conselho Nacional de Pesquisa e Desenvolvimento (CNPq).

\section{REFERENCES}

BAJPAI, A.K. et al. Responsive polymers in controlled drug delivery. Progress in Polymer Science, v.33, p.1088-1118, 2008. Available from: <http:// www.s ciencedirect.com/science/article/pi i/ S0079670008000609>. Accessed: May 12, 2014. doi: 10.1016/J. Progpolymsci.2008.07.005.

BYUN, Y. et al. Formulation And Characterization Of $\alpha$-Tocopherol Loaded Poly $\varepsilon$-Caprolactone (PCL) Nanoparticles. LWT - Food Science and Technology, v.44, p.24-28, 2011. Available from: <http://www.sciencedirect.com/science/ article/pii/S0023643810002501>. Accessed: May 15, 2014. doi: 10.1016/J.Lwt.2010.06.032.

CAN, E. et al. Investigation of PLLA/PCL blends and paclitaxel release profiles. AAPS Pharmscitech, v.12, p.1442-1453, 2011. Available from: <http://dx.doi:10.1208/S12249-011-9714-Y>. Accessed: Apr. 5, 2014. doi: 10.1208/S12249-011-9714-Y.

CAVALLARO, G. et al. Structural investigation of water/ lecithin/cyclohexane microemulsions by FT-IR spectroscopy. Journal of Colloid and Interface Science, v.176, p.281-285, 1995. Available from: <http://www.sciencedirect.com/ science/article/pii/S0021979785799663>. Accessed: Feb. 282014. doi: $10.1006 /$ Jcis.1995.9966.

CERCHIARA, T. et al. Effect of chitosan on progesterone release from Hydroxypropyl-B-Cyclodextrin complexes. International Journal of Pharmaceutics, v.258, p.209-215, 2003. Available from: $<\mathrm{http} / /$ www.sciencedirect.com/science/article/pii/S0378517303002023>. Accessed: Dec. 7, 2013. doi: 10.1016/S0378-5173(03)00202-3.

CHAWLA, J.S.; AMIJI, M.M. Biodegadable poly ( $\varepsilon$-caprolactone) nanoparticles for tumor-targeted delivery of tamoxifen. International Journal of Pharmaceutics, v.249, p.127-138, 2002. Available from: <http://www.sciencedirect.com/science/ article/pii/S0378517302004830>. Accessed: Feb. 20, 2015. doi: 10.1016/S0378-5173(02)00483-0.

CHORNY, M. et al. Lipophilic drug loaded nanospheres prepared by nanoprecipitation: effect of formulation variables on size, drug recovery and release kinetics. Journal of Controled Release, v.83, p.389-400, 2002. Available from: <http://www. sciencedirect.com/science/article/pii/S0168365902002110>, Accessed: Dec. 1, 2013. doi: 10.1016/S0168-3659(02)00211-0.
DAS, R.K. et al. Encapsulation of curcumin in alginate-chitosanpluronic composite nanoparticles for delivery to cancer cells. Nanomedicine, v.6, p.153-160, 2010. Available from: <http:// www.ncbi.nlm.nih.gov/pubmed/19616123>. Accessed: Jul. 11, 2011. doi: 10.1016/J.Nano.2009.05.009.

DEV,A. et al. Preparation of poly(LacticAcid)/Chitosan nanoparticles for anti-HIV drug delivery applications. Carbohydrate Polymers, v.80, p.833-838, 2010. Available from: <http://www.sciencedirect. com/science/article/pii/S0144861710000020>. Accessed: Aug. 30, 2011. doi:10.1016/J.Carbpol.2009.12.040.

EDWARDS, W.L. et al. Raman spectroscopic study of boundary lipid in 1,2-Dipalmitoylphosphatidylcholine/Apolipoprotein A-I recombinants. Spectrochimica Acta Part A: Molecular Spectroscopy, v.49, p.2027-2038, 1993. Available from: <http:// www.sciencedirect.com/science/article/pii/S0584853909910133>. Accessed: Mar. 15, 2010. doi: 10.1016/S0584-8539(09)91013-3.

HYON, S.-H. et al. Synthesis of polylactides with different molecular weights. Biomaterials, v.18, p.1503-1508, 1997. Available from: $<\mathrm{http}: / /$ www.sciencedirect.com/science/article/pii/S0142961297000768>. Accessed: Mar. 15, 2010. doi: 10.1016/S0142-9612(97)00076-8.

JAMEELA, S.R. et al. Progesterone-loaded chitosan microspheres: a long acting biodegradable controlled delivery system. Journal of Controled Release, v.52, p.17-24, 1998. Available from: <http:// www.sciencedirect.com/science/article/pii/S0168365997001879>. Accessed: Oct. 29, 2009. doi: 10.1016/S0168-3659(97)00187-9.

KIETZKE, T. et al. Novel approaches to polymer blends based on polymer nanoparticles. Nature Materials, v.2, p.408-412, 2003. Available from: <http:// www.nature.com/nmat/journal/v2/n6/full/nmat 889 .html $>$. Accessed: Out. 29, 2009. doi:10.1038/Nmat889.

LANCASTER, R.W. et al. The polymorphism of progesterone: stabilization of a "disappearing" polymorph by co-crystallization. Journal of Pharmaceutical Sciences, v.96, p.3419-3431, 2007. Available from: $<$ http://dx.doi.org/10.1002/jps.20983>. Accessed: Out. 29, 2009. doi: 10.1002/Jps.

KUMARI, A. et al. Biodegradable polymeric nanoparticles based drug delivery systems. Colloids and Surfaces B: Biointerfaces, v.75, p.1-18, 2010. Available from: <http://www.sciencedirect. com/science/article/pii/S0927776509004111>. Accessed: Oct. 27, 2011. doi: 10.1016/j.colsurfb.2009.09.001.

LATHA, M.S. et al. Progesterone release from glutaraldehyde cross-linked casein microspheres: in vitro studies and in vivo response in rabbits. Contraception, v.61, p.329334, 2000. Available from: <http://www.sciencedirect.com/ science/article/pii/S001078240000113X $>$. Accessed: Oct. 27, 2011. doi: 10.1016/S0010-7824(00)00113-X.

LEIMANN, F.V. et al. Hydrolysis of poly(Hydroxybutyrate- Co -Hydroxyvalerate) nanoparticles. Journal of Applied Polymer Science, v.128, p.3093-3098, 2013. Available from: <http:// onlinelibrary.wiley.com/doi/10.1002/app.38506/full>. Accessed: Feb. 20, 2014. doi: 10.1002/App.38506.

LEMOS-SENNA, E. et al. Preparation of amphiphilic cyclodextrin nanospheres using the emulsification solvent evaporation method. Influence of the surfactant on preparation and hydrophobic drug loading. International Journal of Pharmaceutics, v.170, p.119- 
128, 1998. Avaliable from: <http:/www.sciencedirect.com/ science/article/pii/S0378517398001471>. Accessed: Mar. 27, 2009. doi: 10.1016/S0378-5173(98)00147-1

LIU, J. et al. Polymer-drug compatibility: a guide to the development of delivery systems for the anticancer agent, ellipticine. Journal of Pharmaceutical Sciences, v.93, p.132-143, 2004. Available from: <http://www.sciencedirect.com/science/ article/pii/S0378517398001471>. Accessed: Oct. 27, 2009. doi: $10.1002 /$ Jps. 10533 .

MATSUMOTO, J. et al. Preparation of nanoparticles consisted of poly(L-Lactide)-Poly(Ethylene Glycol)-Poly(L-Lactide) and their evaluation in vitro. International Journal of Pharmaceutics, v.185, p.93-101, 1999. Available from: <http://www.sciencedirect. com/science/article/pii/S0378517399001532>. Accessed: Nov. 25, 2008. doi: 10.1016/S0378-5173(99)00153-2.

MUSYANOVYCH, A. et al. Preparation of biodegradable polymer nanoparticles by miniemulsion technique and their cell interactions. Macromolecular Biosciences, v.8, p.127-139, 2008. Available from: <http://www.sciencedirect.com/ science/article/pii/S0378517399001532>. Accessed: Mar. 24, 2009. doi: 10.1002/Mabi.200700241.

NEVES, J.P. et al. Scientific progress in reproduction research during the first decade of XXI century. Revista Brasileira de Zootecnia, v.39, p.414-421, 2010. Available from: $<$ http://dx.doi. org/10.1590/S1516-35982010001300046>. Accessed: Apr. 30, 2014. doi: 10.1590/S1516-35982010001300046.

NIJENHUIS, A.J. et al. Lewis acid catalyzed polymerization of L-Lactide. Kinetics and mechanism of the bulk polymerization. Macromolecules, v.25, p.6419-6424, 1992. Available from: $<$ http://pubs.acs.org/doi/abs/10.1021/ma00050a006>. Accessed: Mar. 24, 2009. doi: 10.1021/ma00050a006.

PATTERSON, D.J. et al. Control of estrus and ovulation in beef heifers. Veterinary Clinics of North America: Food Animal Practice, v.29, p.591-617, 2013. Available from: $<$ http://www. sciencedirect.com/science/article/pii/S0749072013000613>. Accessed: Jun. 15, 2014. doi: 10.1016/J.Cvfa.2013.07.009.

PEREIRA, G.R. etal.Arapidmethod fordetermination of progesteroneby reversed-phase liquid chromatography from aqueous media. Analytical Letters, v.3, p.881-889, 2000. Available from: $<$ http://www.tandfonline. com/doi/abs/10.1080/00032710008543096\#.VUulLZVFDVI>. Accessed: Mar. 24, 2009. doi:10.1080/00032710008543096.

PIMENTEL, J.R.V. Liberação sustentada de progesterona em micro partículas de PHB-V e PHB-V / PCL produzidas em meio super-critico. 2010. 140 f. Dissertação (Mestrado em Reprodução Animal) - Universidade De São Paulo, SP.

POLETTO, F.S. et al. Rate-modulating PHBHV/PCL microparticles containing weak acid model drugs. International Journal of
Pharmaceutics, v.345, p.70-80, 2007. Available from: <http:// www.sciencedirect.com/science/article/pii/S037851730700470X $>$. Accessed: Mar. 24, 2009. doi: 10.1016/J.Ijpharm.2007.05.040.

RATHBONE, M.J. et al. Development of an injection molded poly ( $\varepsilon$-Caprolactone) intravaginal insert for the delivery of progesterone to cattle. Journal of Controled Release, v.85, p.61-71, 2002. Available from: <http://www. sciencedirect.com/science/article/pii/S0168365902002729>. Accessed: Mar. 24, 2009. doi: 10.1016/S0168-3659(02)00272-9.

RATHBONE, M.J. et al. Controlled-release products for the control of the estrus cycle in cattle, sheeps goats, deer, pigs and horses. Critical Reviews in Therapeutic Drug Carrier Systems, v.15, p.285-380, 1998.

RUGGIRELLO, A.; TURCO LIVERI, V. FT-IR investigation of the urea state in lecithin and sodium bis(2-Ethylhexyl) phosphate reversed micelles. Journal of Colloid and Interface Sciences, v.258, p.123-129, 2003. Available from: <http://www. sciencedirect.com/science/article/pii/S0021979702000735>. Accessed: Mar. 24, 2009. doi:10.1016/S0021-9797(02)00073-5.

SALEM, H.F. Sustained-release progesterone nanosuspension following intramuscular injection in ovariectomized rats. International Journal of Nanomedicine, v.5, p.943-954, 2010. Available from: <http:// www.dovepress.com/sustained-release-progesterone-nanosuspensionfollowing-intramuscular--peer-reviewed-article-IJN\#>. Accessed: Jun. 15, 2014. doi: 10.2147/IJN.S12947.

SAWANT, P.D. Drug release from hydroethanolic gels. Effect of drug's lipophilicity (Logp), polymer-drug interactions and solvent lipophilicity. Internatonal Journal of Pharmaceutics, v.396, p.45-52, 2010. Available from: <http://www.sciencedirect. com/science/article/pii/S0378517310004163>. Accessed: Jun. 15, 2014. doi:10.1016/J.Ijpharm.2010.06.008.

SILVA, J.F.S.F. et al. Avaliação da dinâmica útero-ovárica da égua sob o efeito de um implante subcutâneo de micro-cápsulas de polihidroxibutirato contendo progesterona. Revista Portuguesa de Ciências Veterinárias, v.101, p.225-230, 2006. Available from: <http://www.fmv.utl.pt/spcv/PDF/pdf12_2006/225-230.pdf >. Accessed: Sep. 14, 2014.

SOUZA, L.G. et al. Development of topotecan loaded lipid nanoparticles for chemical stabilization and prolonged release. European Journal of Pharmaceutics and Biopharmaceutics, v.79, p.189-196, 2011. Available from: <http://www.sciencedirect. com/science/article/pii/S0939641111000786>. Accessed: Mar. 25, 2012. doi: 10.1016/J.Ejpb.2011.02.012.

WEST, J.L.; HALAS, N.J. Applications of nanotechnology to biotechnology: commentary. Current Opinion in Biotechnology, v.11, p.215-217, 2000. Available from: <http://www.sciencedirect. com/science/article/pii/S0958166900000823> . Accessed: Mar. 25, 2012. doi: 10.1016/S0958-1669(00)00082-3. 